\title{
Molecular design and anti-melanoma activity of a novel bullfrog antibacterial peptide RGD-chimera
}

\author{
MENGYUE LIU* ${ }^{*}$ XUAN JIANG ${ }^{*}$, CHAO FU, RUILI ZHAO, TIANMING JIN, \\ JIFEI MA, SHUNYI QIN, LIU AN LI, YE HU and XIN ZHANG
}

\begin{abstract}
Tianjin Key Laboratory of Agricultural Animal Breeding and Healthy Husbandry, College of Animal
Science and Veterinary Medicine, Tianjin Agricultural University, Tianjin 300384, P.R. China
\end{abstract}

Received December 26, 2019; Accepted October 20, 2020

DOI: $10.3892 / \mathrm{ol} .2020 .12376$

\begin{abstract}
Melanoma is a common malignant skin tumor, which is the only fatal skin tumor at present. Melanoma has a high degree of malignancy and metastasis. The activity of modified Temporin-La (T-La) peptides from bullfrog skin were evaluated for antitumor activity and improved targeting in melanoma cells. The amino acid sequence of T-La was modified, resulting in the antitumor peptide, T-La (FS). T-La and T-La (FS) were coupled to the RGD small molecule polypeptide to form the chimeric peptides RGD-T-La and RGD-T-La (FS), respectively. The secondary structures for the peptides, evaluated using circular dichroism, were found to be $\alpha$-helical. The structure of T-La was evaluated using bioinformatics. In addition, the antitumor effects of the modified peptide and the targeting of RGD chimeric peptide to the tumor in vivo and in vitro were analyzed. Antitumor activity was measured in vitro using the MTT assay. Tumor cells with high integrin $\alpha v \beta 3$ expression were detected using flow cytometry, and tumor cells were screened for sensitivity to RGD-T-La (FS) to establish a tumor model in nude mice. The effects of the peptides on tumor cells were measured using laser confocal microscopy in real-time. The mechanism of the peptide antitumor activity in tumor cells was evaluated with scanning electron microscopy. B16 melanoma cells were the most sensitive to the peptides, for which the cell survival
\end{abstract}

Correspondence to: Professor Ruili Zhao or Professor Tianming Jin, Tianjin Key Laboratory of Agricultural Animal Breeding and Healthy Husbandry, College of Animal Science and Veterinary Medicine, Tianjin Agricultural University, 22 Jinjing Road, Tianjin 300384, P.R. China

E-mail: zhaoruili1109@126.com

E-mail: jtm680@163.com

*Contributed equally

Abbreviations: T-La, Temporin-La; FITC, fluorescein isothiocyanate; T-La (FS), Temporin-La (FS)

Key words: antitumor peptide, RGD-chimera, targeting, antitumor effect, melanoma cells rate was $24.65 \%$ for $10 \mu \mathrm{g} / \mathrm{ml}$ RGD-T-La (FS). RGD-La (FS) had a rapid effect on tumor cells. RGD chimeric polypeptides exhibited site-targeting cytotoxic effects in tumor cells. In the B16 melanoma mouse model, the peptides exhibited antitumor effects against early melanoma development and induced tumor apoptosis, possibly by inhibiting VEGF and promoting caspase- 3 expression. Overall, the present study provides a scientific basis for the application of small molecule antimicrobial peptides as targeted antitumor agents and lays the foundation for the clinical application of these peptides as antitumor drugs.

\section{Introduction}

Amphibian antimicrobial peptides (AMPs) are important components of the amphibian innate immune system (1). AMPs have a wide range of biological activities, including antibacterial, antiviral and antiparasitic activities (2). In addition, AMPs have antitumor activity (3). Previous studies have shown that Temporin-La (T-La), a peptide isolated from a bullfrog skin cDNA library, has antitumor activity and mild hemolytic activity $(4,5)$. Antitumor drugs exploit biological characteristics of tumor cells (6) to target the biological activity to specific tissues, cells or organs (7), while sparing normal cells, tissues and non-target organs (8). Improved targeting of antitumor drugs will improve treatment efficacy, while reducing toxicity (9). Integrin $\alpha v \beta 3$, which is highly expressed on the surface of certain tumor cells, can be exploited to improve antitumor drug targeting (5). Integrin $\alpha v \beta 3$ is also expressed on endothelial cells in the basement membrane, which is traversed by migrating tumor cells (10). The RGD peptide is a small molecule peptide, containing three amino acids, that specifically binds to integrin $\alpha v \beta 3(11,12)$. Thus, the specific binding qualities and small size of the RGD peptide can be exploited to improve the targeting and efficacy of antitumor drugs.

The present study evaluated the antitumor properties of the T-La peptide and T-La derivatives. To improve the targeting of T-La to tumor cells and to decrease its cytotoxicity, the amino acid sequence was altered and an RGD chimeric T-La peptide was designed, called T-La (FS), using bioinformatics methods and analyses. The secondary structure of T-La (FS) was determined. Tumor targeting of the polypeptides 
was assessed in vivo and the effects of the peptides on apoptosis-related protein caspase- 3 and endothelial growth factors were evaluated. The inhibitory effects of T-La (FS) on tumor growth were determined. The present study provides the scientific basis for the application of small molecule antimicrobial peptides as anti-tumor agents. Furthermore, the current study aimed to establish the theoretical foundation for the development and clinical application of these peptides as antitumor drugs.

\section{Materials and methods}

Database. Peptide (Temporin-La) details were obtained from the Antibacterial Peptide Database (http://aps.unmc. edu/AP/main.php), which characterizes various antimicrobial peptides.

Software. Protein sequence analyses were performed using the ExPasy sequence analysis and protein analysis tools (https://web.expasy.org/protparam/). The secondary structure was analyzed using the Spiral online analysis software (http://heliquest.ipmc.cnrs.fr/). Chemical structure simulation was performed using the PyMoL Molecular Graphics System software version 1.5.0.4 (Schrödinger, LLC. http://sourceforge. net/projects/pymol).

Samples. Polypeptides were synthesized by Zhejiang Hongtuo Biotechnology Co., Ltd. using solid phase synthesis. Samples were desalted and purified (95\% purity) using HPLC (Agilent high performance liquid chromatography, Agilent Technology Co., Ltd., Waters 600 controller) reverse phase C18 column (Agilent ZORBAX; cat. no. 300SB-C18 $5 \mu \mathrm{m} ; 4.6 \times 250 \mathrm{~mm}$; Agilent Technology Co., Ltd.) chromatography. The whole liquid phase system was used at room temperature and the composition of mobile phase was $\mathrm{A}, 0.1 \%$ TFA in $\mathrm{H}_{2} \mathrm{O}$ and $\mathrm{B}, 0.1 \% \mathrm{TFA}$ in $100 \% \mathrm{ACN}$; The sample quantity of the system was $20 \mu \mathrm{l}$ and the flowrate was $1.0 \mathrm{ml} / \mathrm{min}$. The molecular mass was determined using fast atom bombardment mass spectrometry (Applied Biosystems 3200 QTRAP LC/MS/MS; Applied Biosystems Inc.). The positive ionization mode was used in the mass spectrometer and the details were as follows: nitrogen gas temperature $\left(350^{\circ} \mathrm{C}\right)$, nebulizer pressure $(40 \mathrm{psi})$ and flow rate $(0.3 \mathrm{ml} / \mathrm{min})$.

Reagents. Reagents used in the present study included RPMI-1640 (pH 7.2) medium, high-sugar DMEM medium (Beijing Solarbio Science \& Technology Co., Ltd.), South American fetal bovine serum (Gibco; Thermo Fisher Scientific, Inc.), dimethyl sulfoxide (DMSO), trypsin, penicillin-streptomycin, MTT, DAPI nuclear stain (Beijing Zhongsheng Ruitai Technology Co., Ltd.), 3\% glutaraldehyde (Alfa Aesar; Thermo Fisher Scientific, Inc.) mouse Anti-Human CD61 PE-labeled antibody (Beijing Solarbio Science \& Technology Co., Ltd.), cisplatin (Qilu Pharmaceutical), 10\% sheep serum (NGS; Shanghai Biosun Sci\&Tech Co., Ltd.) and $0.05 \%$ DAB containing $0.03 \%$ hydrogen peroxide (protected from light). The cell endothelial growth factor VEGF (1:100; cat. no. 251659) and apoptosis-related protein caspase-3 (1:100; cat. no. 341034) primary antibodies and the secondary goat anti-mouse antibodies IgG were obtained from Zen BioScience
Co., Ltd. (1:200; cat. no. 550047). Primary antibodies against cleaved caspase-3 (1:1,000; cat. no. ab13847), GAPDH (1:1,000; cat. no. ab8245) and goat anti-rabbit horseradish peroxidase secondary antibody (1:3,000; cat. no. ab7621) were obtained from Abcam.

Experimental animals. All animal experiments were approved by The Laboratory Animal Ethics Committee of Tianjin Medical University (Tianjin, China). In total, $41 \mathrm{BALB} / \mathrm{c}$ female nude mice, aged 5-6 weeks, weighing 18-22 g, were used. The mice were reared in separate cages to ensure stable atmospheric pressure difference, with sufficient food and water and ambient temperature controlled at $25 \pm 1^{\circ} \mathrm{C}$. The cycle of light and dark was $12 \mathrm{~h}$ alternately. The mice were obtained from a specific pathogen free facility (cat. no. 11400700271441; Beijing Vital River Laboratory Animal Technology Co., Ltd.).

Main instruments used. The following instruments were used in this study: Circular Chromatograph J-715 (JASCO), Microplate Reader (Bio-Rad Laboratories, Inc.), Inverted Fluorescence Microscope (Nikon ECLIPSE Ti; Nikon Corporation), Laser Confocal Microscope (Leica TCS SP5 II; Leica Microsystems, Inc.), Scanning Electron Microscope QUANTA 200 (Thermo Fisher Scientific, Inc.), small animal imaging system (Kodak), automatic dyeing machine (LEICA ST5010) paraffin embedding machine (LEICA EG1150H), and rotary slicer (LEICA RM2235) (all Leica Microsystems, Inc.).

Cell lines. Melanoma cells (B16; Hunan Fengh Biotech Co., Ltd.), hepatoma cells (Huh-7.5.1; Veterinary Laboratory of Tianjin Agricultural University), mouse fibroblast cells (NIH-3T3), mouse hepatoma cells (HEPA1-6), human lung cancer cells (NCI-H460), human hepatoma cells (HepG2) and human breast cancer cells (MCF7) were a gift from the Institute of Radiology, Chinese Academy of Sciences.

Bioinformatics analysis of antimicrobial peptide sequences. Peptide sequences were entered into http://www.expasy. ch/cgi-bin/protparam and http://heliquest.ipmc.cnrsunitr/ to analyze the physical and chemical properties of the antimicrobial peptide molecules. The following parameters were obtained: Net charge, hydrophobicity, hydrophobic torque and amphiphilicity.

Secondary structure prediction and $3 D$ structure simulation of polypeptides using circular dichroism (CD) spectrum analysis. The CD spectrum was measured using a Jasco J-715 circular dichroic instrument equipped with a Peltier type temperature control system. Molar ellipticity $(\theta)$ unit $\mathrm{deg} / \mathrm{cm}^{2} \cdot \mathrm{dmol}$, was calculated using the formula $[\theta]=100 \theta /(\mathrm{cl})$, where $\mathrm{c}$ is the molar concentration of the polypeptide, and 1 is the thickness $(\mathrm{cm})$ of the specific cuvette. The CD spectrum was processed using Origin 7.5 software (Origin Lab). The 3D structural simulation of several antitumor peptides was plotted using the PyMoL Molecular Graphics System chemical structure simulation software.

MTT assay to detect the inhibitory activity of the polypeptides on tumor cells. Seven tumor cell lines (B16, huh7, 3T3, HEPA1-6, H460, HepG2 and MCF7) were used in the present 
study. The cells were cultured in 96-well plates at a concentration of $5 \times 10^{3}$ cells per well in a $100 \mu \mathrm{l}$. After $24 \mathrm{~h}$ incubation at $37^{\circ} \mathrm{C}$ and $5 \% \mathrm{CO}_{2}$, the four different antitumor peptides were added at final concentrations of 200,50, 10, 5 and $1 \mu \mathrm{g} / \mathrm{ml}$ in $200 \mu \mathrm{l}$ per well. Our preliminary experiment results demonstrated that the cell survival rate of $100 \mu \mathrm{g} / \mathrm{ml}$ peptides was basically 0 for tumor cells (data not shown). In order to investigate the high concentration toxicity of peptides to tumor cells, $200 \mu \mathrm{g} / \mathrm{ml}$ was chosen for the present study. There were five experimental replicates per group. Plates were incubated at $37^{\circ} \mathrm{C}$ and $5 \% \mathrm{CO}_{2}$ for $24 \mathrm{~h}$. MTT $(20 \mu \mathrm{lof} 5 \mathrm{mg} / \mathrm{ml})$ was added to each well, and the plates were incubated at $37^{\circ} \mathrm{C}$ for $4 \mathrm{~h}$. The culture medium was removed and $150 \mu \mathrm{l}$ DMSO was added into each well. The crystals were thoroughly dissolved and the absorbance (OD value) of each well (wavelengths 490 or $630 \mathrm{~nm}$ ) was measured with a microplate reader. Each experiment was repeated three times, and the cell proliferation inhibition rate was calculated according to the following formula: Cell proliferation inhibition rate $(\%)=(1$-average $\mathrm{OD}$ value of the experimental group/average OD value of the normal control group)x $100 \%$.

Real-time observation of the effects of the polypeptides on cell morphology. The B16 melanoma cell line was sensitive to the polypeptides, as indicated by the MTT assay. B16 cells were inoculated on a laser confocal cell culture dish and cultured to $80 \%$ confluence at $37^{\circ} \mathrm{C}$ and $5 \% \mathrm{CO}_{2}$. Fluorescein isothiocyanate (FITC)-labeled polypeptides were incubated with the tumor cells at a final concentration of $25 \mu \mathrm{g} / \mathrm{ml}$. Then, DAPI (nuclear stain) was added for $10 \mathrm{~min}$ at room temperature. Real-time acquisition was performed using a confocal microscope (FluoView FV1000; Olympus Corporation) (magnification, x100). Images were captured every 10-20 min for $2 \mathrm{~h}$, while cells were maintained at $37^{\circ} \mathrm{C}$.

Effects of polypeptide treatment on the tumor cell membrane. B16 melanoma cells were added to 6 -well plates containing sterile cell slides at a density of $5 \times 10^{5}$ cells/well. Cells were cultured for $12 \mathrm{~h}\left(37^{\circ} \mathrm{C}\right.$ and $\left.5 \% \mathrm{CO}_{2}\right)$ to reach $80 \%$ confluence. Antitumor peptides were added to the cells at 50, 10, 5 and $1 \mu \mathrm{g} / \mathrm{ml}$ for $48 \mathrm{~h}$. Cells were then collected, washed with PBS three times and fixed with 3\% glutaraldehyde for $2 \mathrm{~h}$ at room temperature. After incubation at $4^{\circ} \mathrm{C}$ for $15 \mathrm{~min}$, cells were washed three times in PBS. Cells were dehydrated using a step-by-step ethanol gradient at 30, 50, 70 and $90 \%$ for $15 \mathrm{~min}$ each step. Final dehydration in $100 \%$ ethanol was performed three times for 10 min each. Samples were dried using the critical point drying method (13) and then the samples were coated and sprayed with gold, after adhering to the sample table.

Detection of cell surface integrin $\alpha v \beta 3$ expression. Cells without polypeptide were selected as normal controls, and $1 \times 10^{6}$ HepG2, 3T3, MCF7 or HEPA1-6 cells were incubated with mouse anti-human CD61 PE-labeled antibody at $4^{\circ} \mathrm{C}$ for $10 \mathrm{~min}$. The fluorescence intensity was measured by flow cytometry (BD FACS Aria III; Becton, Dickinson and Company). BD Accurate C6 software version 1.0.264.21 (Becton, Dickinson and Company) was used for data analysis. Differences in the cell surface expression of integrin $\alpha v \beta 3$ were evaluated.
Detection of caspase-3 apoptotic protein expression. After reaching $\sim 80 \%$ confluency, B16 cells were collected and diluted with cell culture medium (RPMI-1640) to $7 \times 10^{4}$ cells $/ \mathrm{ml}$. The cells were added to 6 -well plates $(2 \mathrm{ml}$ per well) and treated with peptides at final concentrations of $10,20,50$, and $100 \mu \mathrm{g} / \mathrm{ml}$ for $24 \mathrm{~h}$. B16 cells which had PBS added were the control group. After washing cells three times with PBS, NP-40 was added and the cells were incubated at $4^{\circ} \mathrm{C}$ for $1 \mathrm{~h}$. The cells were then collected and stored at $-80^{\circ} \mathrm{C}$ or used immediately.

Samples were centrifuged $\left(12,000 \times \mathrm{g}\right.$ for $5 \mathrm{~min}$ at $\left.4^{\circ} \mathrm{C}\right)$ and the supernatants were collected. The total protein concentration was measured using the BCA method. Loading buffer was added to each sample (50 ng total protein) and the samples were boiled. Samples were separated using 15\% SDS-PAGE electrophoresis and transferred to a PVDF membrane using the semi-dry method (14). After blocking with 5\% skimmed milk at $4^{\circ} \mathrm{C}$ overnight, cleaved caspase- 3 and GAPDH primary antibodies were added and the membrane was incubated for $1.5 \mathrm{~h}$ at room temperature. After incubation with horseradish peroxidase-labeled goat anti-rabbit secondary antibodies for $1 \mathrm{~h}$ at room temperature, the bound secondary antibodies were detected with enhanced chemiluminescence (ECL Chemiluminescent Substrate Reagent kit; Thermo Fisher Scientific Inc.). Image J software (version $1.51 \mathrm{q}$ and $\mathrm{k}$; National Institutes of Health) was used to analyze the gray value of each band, and the target protein to GAPDH ratio was determined.

Reverse transcription-quantitative $(R T-q) P C R$ analysis of apoptotic gene $m R N A$ expression. After reaching $\sim 80 \%$ confluency, B16 cells were collected and diluted with cell culture medium to $7 \times 10^{4}$ cells $/ \mathrm{ml}$. B16 cells were added to 6-well plates. After overnight culture, the cells were treated with different concentrations of polypeptides (20,50 and $100 \mu \mathrm{g} / \mathrm{ml}$ ) and the control group was untreated. After $24 \mathrm{~h}$, cells were collected for total RNA extraction according to the RNA extraction kit (RNAprep pure Cell kit; TIANGEN Biotech Co., Ltd.) instructions. The RNA concentration was determined. RNA was reverse transcribed into cDNA for PCR amplification, The reverse transcription program was $45^{\circ} \mathrm{C}$ for 10 min (UltraSYBR Mixture; ComWin Biosciences). The PCR reaction procedure was as follows: pre-denaturation at $95^{\circ} \mathrm{C}$ for $10 \mathrm{~min}$; denaturation at $95^{\circ} \mathrm{C}$ for $15 \mathrm{sec}$, annealing/extension at $60^{\circ} \mathrm{C}$ for $1 \mathrm{~min}$, total 35 cycles. The PCR primers sequences were as follows: GAPDH forward, 5'-GCACAGTCAAGG CTGAGAATG-3' and reverse 5'-ATGGTGGTGAAGACG CCAGTA-3'; caspase 3 forward, 5'-CTGGACTGTGGCATT GAGAC-3' and reverse 5'-ACAAAGCGACTGGATGAACC-3'. Quantitative analysis was performed on a real-time PCR instrument using SYBR-Green dye and the final data was analyzed using the $2^{-\Delta \Delta \mathrm{Cq}}$ method (13).

Targeted distribution of RGD-chimeric peptide in nude mice Establishment of a liver tumor model. In total, 15 BALB/c nude mice were randomly divided into three groups, RGD-T-La (FS) group, T-La (FS) group and a blank control group, with five mice in each group. The mouse model of subcutaneous transplantation of HepG2 hepatoma cells was established according to a previous study (12). The concentration of HepG2 cells was adjusted to $10^{6}$ cells $/ \mathrm{ml}$. The cells were injected subcutaneously (100 $\mu \mathrm{l} /$ mouse) in the axillary 
posterior part of the forelimbs. When tumors developed to $\sim 5 \mathrm{~mm}$ in diameter, RGD-T-La (FS) or T-La (FS) was injected into the tail vein at a dose of $100 \mu \mathrm{l} /$ mouse $(2 \mu \mathrm{mol} / \mathrm{ml})$. The blank control group was injected with PBS $100 \mu \mathrm{l} /$ mouse.

Distribution of antitumor peptides in mice. After injection of RGD-T-La (FS), T-La (FS) or PBS, the heart, liver, spleen, lung, kidney and tumor tissues were collected from mice at $30 \mathrm{~min}, 1,2,4$ and $8 \mathrm{~h}$ post injection. The fluorescence distribution and intensity of FITC-labeled antitumor peptide was observed using a small animal imaging system and compared with the blank group.

Making pathological slices of subcutaneous liver tumors. Pathological sections of liver tumors were made according to the method described by Ji and Zhang (13).

Therapeutic effects of RGD-chimeric peptides on melanoma in a nude mouse model

Subcutaneous melanoma model in nude mice. In total, 36 female BALB/c nude mice, aged 5-6 weeks, were randomly divided into six groups ( $n=6$ per group): i) T-La (FS); ii) RGD-T-La (FS); iii) T-La; iv) RGD-T-La; v) Cisplatin (positive control); and vi) PBS (blank control). B16 melanoma cells were adjusted to $5 \times 10^{5}$ cells $/ \mathrm{ml}$ in saline suspension and each mouse was inoculated subcutaneously into the forelimb axilla with $0.1 \mathrm{ml}$ of the cell suspension. The success of tumor growth was confirmed visually when the tumor reached $\sim 5 \times 5 \mathrm{~mm}^{2}$, and the tumor sizes in each group were measured. Mice in each group were injected with the corresponding drug treatments $(600 \mu \mathrm{g} / \mathrm{ml}$ of peptide). The positive control group was treated with $1 \mathrm{mg} / \mathrm{ml}$ cisplatin solution prepared in saline and injected through the tail vein.

Effects of antitumor peptides on melanoma growth in vivo. Drug treatments were administered every $48 \mathrm{~h}$ for 10 days (five doses in total). Tumor growth in each group was recorded. Nude mice were weighed, the tumor volume was measured with an electronic Vernier caliper $\left(\mathrm{Vmm}^{3}=1 / 2 \times\right.$ length $=\mathrm{x}$ width $)$ before each drug administration, and the mental state of the mice was observed. One week after the last administration, the final weight and tumor measurement were collected. Mice were sacrificed by cervical dislocation after taking blood by removing the eyeball, and necropsy was performed as previously described (6).

Immunohistochemical evaluation of VEGF and caspase-3 expression. Sample slides were subjected to positive charge treatment and the tissue was adsorbed onto the glass slide by electrostatic action $(3,6)$. Mouse tissues were fixed in $4 \%$ paraformaldehyde for $24 \mathrm{~h}$ at room temperature. Tissues were embedded in paraffin blocks and sectioned at a thickness of 4-5 $\mu \mathrm{m}$ per slice. The sections containing the intact tissue were then placed in warm water $\left(40^{\circ} \mathrm{C}\right)$ for spreading. After the tissue was fully flattened, samples were dried at $60-65^{\circ} \mathrm{C}$ for dewaxing. Tissue slices were then placed in sodium citrate, boiled for $2.5 \mathrm{~min}$, and prepared at high temperature $\left(210^{\circ} \mathrm{C}\right)$ and high pressure $\left(1.8 \times 10^{5} \mathrm{~Pa}\right)$ for antigen retrieval. After antigen retrieval, samples were cooled to room temperature, and the citrate buffer was removed. Samples were washed twice with water and then twice with PBS, for 5 min per wash. After drying, the tissue sections were blocked with $10 \%$ NGS for $30 \mathrm{~min}$ at $37^{\circ} \mathrm{C}$, followed by incubation in a wet box for $30 \mathrm{~min}$. Samples were then incubated with primary antibody in 10\% NGS (VEGF and apoptosis-related protein caspase-3 antibodies, dilution ratio 1:100) in the wet box overnight at $4^{\circ} \mathrm{C}$. The following day, samples were placed at room temperature for $1 \mathrm{~h}$ and washed three times with PBST, for $5 \mathrm{~min}$ each wash. Then, samples were incubated with the secondary antibody horseradish peroxidase labeled goat-anti-mouse IgG (diluted 1:500) for $2 \mathrm{~h}$ at room temperature. After incubation with the secondary antibody, the sample was washed three times with PBS for 5 min per wash. According to the kit instructions, $50 \mu \mathrm{l}$ concentrated DAB solution was mixed with $1 \mathrm{ml}$ of A solution. DAB coloring solution was added to the washed slices and slices were incubated for $5 \mathrm{~min}$ at room temperature. The color change of the tissue was observed, and the tissue sample was placed in distilled water to stop the reaction. The colored slices were counterstained with hematoxylin for $30 \mathrm{sec}$ at room temperature. The samples were dehydrated with gradient diluted absolute ethanol (70, 80, 90, 95 and $100 \%$ twice) and then sealed. The sections were observed by light microscope (magnification, x200 and x400).

Statistical analysis. The results were processed by Microsoft Excel version 2016 (Microsoft Corporation), Origin version 7.5 (Originlab), and SPSS version 17 (SPSS Inc.). All statistical comparisons were performed using SPSS and presented as the mean \pm standard error of the mean, (SEM) of three or more samples. One-way ANOVA with Dunnett's post hoc test to compare with the control group. $\mathrm{P}<0.05$ was considered to indicate a statistically significant difference.

\section{Results}

Amino acid sequence analysis of the polypeptides. A novel antitumor peptide and an RGD-chimeric peptide were designed and synthesized by analyzing the physical and chemical properties, molecular structure and amphipathicity of the sequence of the bullfrog antibacterial peptide T-La. The sequence, protein structure and spiral properties (Fig. 1) of T-La were evaluated with analysis software to obtain the net charge, hydrophobicity, hydrophobic torque and amphiphilic parameters of several polypeptides (Table I). The net charge number of T-La was +2 . After sequence modification, the first leucine (L) and the tenth glutamic acid (E) were replaced with phenylalanine (F) and serine (S), respectively, resulting in a net charge of +3 . The result of the substitution was an increase in the average hydrophobicity from 0.654 to 0.707 and a decrease in amphipathicity from 0.754 to 0.733 .

\section{Determination of the secondary structure and $3 D$ structure} of antitumor T-La peptides by CD spectrum analysis. The secondary structures of the four peptides derived from T-la were evaluated using CD spectrum (190-250 nm) analysis (Fig. 2). CD spectrum analysis revealed that T-La (FS), the two RGD-chimeras and the bullfrog skin antitumor peptide T-La had $\alpha$-helix structures, similar to the natural antitumor peptide T-La $(4,6,7)$. The sequences of the four antitumor peptides were imported into chemical structure simulation software and visualized using the PyMoL Molecular Graphics system. The simulated 3D $\alpha$-helical structures of 
Table I. Sample name, sequence and physicochemical properties of the antitumor peptides.

\begin{tabular}{|c|c|c|c|c|}
\hline Items & T-La & T-La (FS) & RGD-T-La & RGD-T-La (FS) \\
\hline Sequence & $\begin{array}{c}\text { LLRHV } \\
\text { VKILE } \\
\text { KYL- } \\
\text { NH2 }\end{array}$ & $\begin{array}{c}\text { VKILEKYL- } \\
\text { NH2 }\end{array}$ & $\begin{array}{c}\text { F } \\
\text { LRHVVKIL } \\
\text { S KYL-NH2 }\end{array}$ & $\begin{array}{c}\text { RGD-F } \\
\text { LRHVVKIL S } \\
\text { KYL-NH2 }\end{array}$ \\
\hline Amino acid number & 13 & 13 & 16 & 16 \\
\hline Molecular number & $1,624.05$ & $1,616.03$ & $1,952.37$ & $1,944.35$ \\
\hline Isoelectric point & 9.70 & 10.29 & 9.70 & 10.28 \\
\hline Total residue of negative charge & 1 & 0 & 2 & 1 \\
\hline Total residue of positive charge & 3 & 3 & 4 & 4 \\
\hline Net charge & 2 & 3 & 2 & 3 \\
\hline Instability index & 44.93 & 44.93 & 33.08 & 28.36 \\
\hline Stability & Unstable & Unstable & Stable & Stable \\
\hline Aliphatic index & 194.62 & 164.62 & 158.12 & 133.75 \\
\hline Total average hydrophilicity & 0.600 & 0.731 & -0.037 & 0.069 \\
\hline Hydrophobic, H & 0.654 & 0.707 & 0.420 & 0.463 \\
\hline Hydrophobic torque, $\mu \mathrm{H}$ & 0.754 & 0.733 & 0.594 & 0.578 \\
\hline
\end{tabular}

T-La, Temporin-La; (FS), antitumor.

A

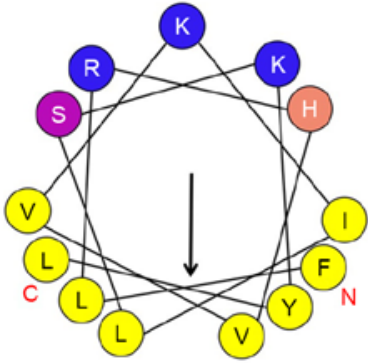

B

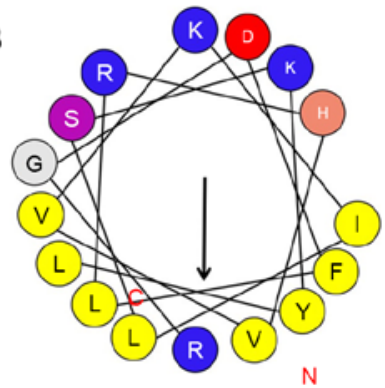

Figure 1. Spiral analysis of the antitumor peptides (A) T-La (FS) and (B) RGD-T-La (FS). Arrows represent the inward spiral structure of polypeptide. Solid lines represent the bond between amino acids. T-La (FS), antitumor Temporin-La.

T-La, T-La (FS) and the chimeric peptides, RGD-T-La and RGD-T-La (FS), are shown in Fig. 2E, F, G and H, respectively.

In vitro cytotoxicity of anti-tumor peptides. The four antitumor peptides were evaluated for in vitro cytotoxicity in seven tumor cell lines: B16, huh7, 3T3, HEPA1-6, H460, HepG2 And MCF7. The dose-dependent effects of the antitumor peptides and the RGD chimeric peptides on cell viability in the seven tumor cell lines are shown in Fig. 3. All peptides, T-La, RGD-T-La, T-La (FS) and RGD-T-La (FS), displayed dose-dependent cytotoxicity. For certain tumor cells, such as B16 and Huh7, the effectiveness of T-La (FS) was higher compared with T-La, and RGD-T-La (FS) was higher compared with RGD-T-La. Among the peptides, RGD-T-La (FS) had the strongest effect on B16 cells, resulting in the lowest cell viability (24.65\%; Fig. 3B).

Disruption of tumor cell morphology and evaluation of the cytotoxic mechanism of the RGD-chimera peptides in tumor cells. After $20 \mathrm{~min}$ of treatment, both fluorescently

labeled polypeptides had entered the cells when observed by confocal microscopy (Fig. 4). At $70 \mathrm{~min}$, the fluorescence profile of FITC-RGD-T-La (FS)-infected cells was incomplete and cellular debris appeared around the nucleus, indicating that FITC-RGD-T-La (FS) disrupted the cell membrane of B16 cells (Fig. 4D). By 110 min, intact cellular morphology was difficult to detect and nuclear shrinkage occurred in cells treated with FITC-RGD-T-La (FS) (Fig. 4A-F).

B16 cells treated with the polypeptide were evaluated by scanning electron microscopy. The structure of the B16 cells changed significantly with increasing polypeptide concentration (Fig. 4G-L). B16 cells treated with $50 \mu \mathrm{g} / \mathrm{ml} \mathrm{RGD-T-La}$ (FS) exhibited cell shrinkage and breakage between cells (Fig. 4H). Treatment of B16 cells with $200 \mu \mathrm{g} / \mathrm{ml}$ RGD-T-La (FS) resulted in the isolation of individual cells, cytoplasm leakage, loss of intact cell morphology and central cell depression (Fig. 4I). Treatment of B16 cells with $50 \mu \mathrm{g} / \mathrm{ml} \mathrm{T-La}$ (FS) resulted in disruption in morphology and partial loss of cytoplasm (Fig. 4K). There were few cellular features visible in B16 cells treated with $200 \mu \mathrm{g} / \mathrm{ml} \mathrm{T-La} \mathrm{(FS)} \mathrm{(Fig.} \mathrm{4L).}$

Detection of cell surface expression of integrin $\alpha v \beta 3$. Expression of integrin $\alpha v \beta 3$ was evaluated on the cell surface of MCF7, HEPA1-6, HepG2 and 3T3 cells using flow cytometry. The same number of events was recorded for each cell line $\left(1 \times 10^{6}\right)$. Fluorescent profiles were different amongst cell lines, indicating differences in expression of integrin $\alpha v \beta 3$ on the cell surface (Fig. 5A). The absorption intensity for HepG2, MCF7, 3T3 and HEPA1-6 cells for FITC-RGD-T-La (FS) was 800,950.70, $763,824.54,675,429.46$ and $661,462.48$, respectively; the absorption intensity for FITC-T-La was 424,694.19, 767,889.04, 502,185.53 and 279,975.88, respectively. Absorption intensity in the blank control group was 5,773.83, 3,836.19, 6,755.40 and 4,793.72, respectively (Fig. 5B). 

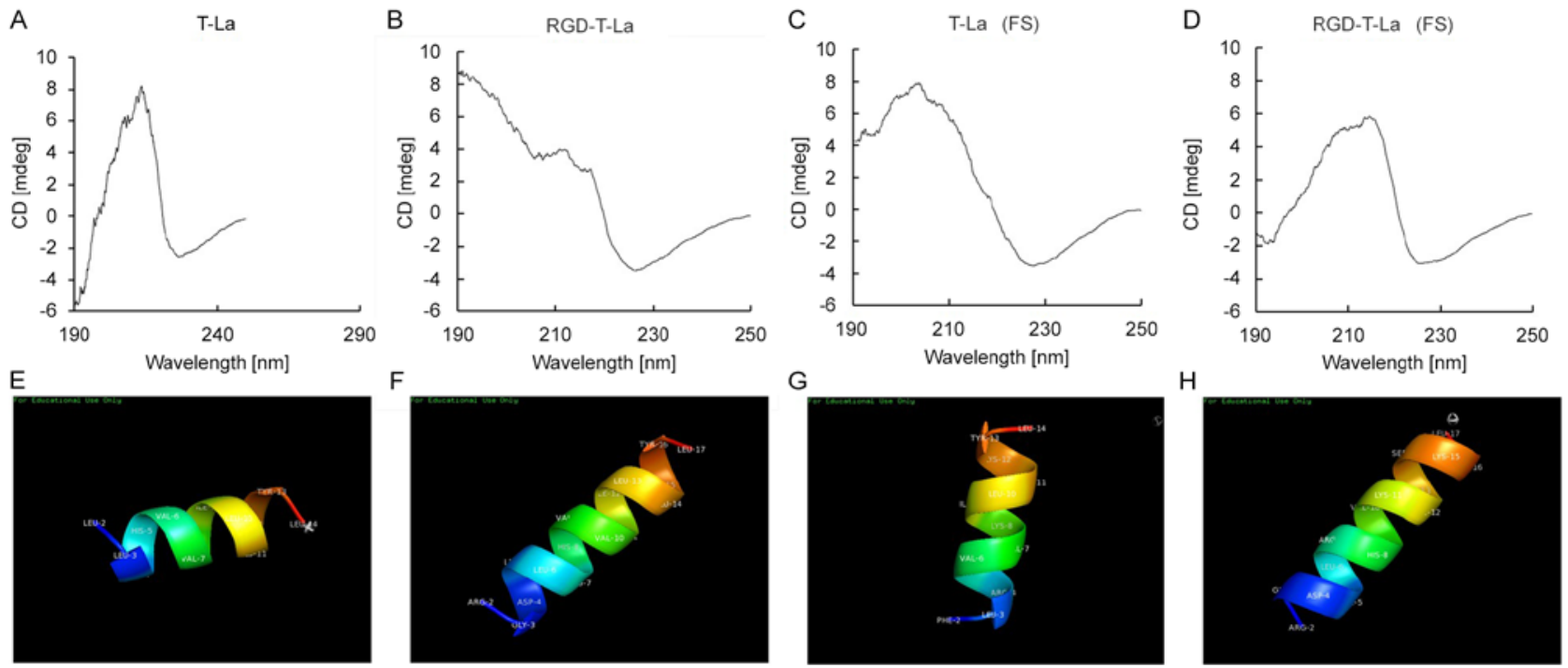

Figure 2. Circular dichroism and 3D structural simulation of natural anti-tumor peptides, engineered peptides and their RGD chimeras, including (A) T-La, (B) RGD-T-La, (C) T-La (FS) and (D) RGD-T-La (FS). Structural 3D simulation of polypeptide $\alpha$-helix for (E) T-La, (F) RGD-T-La, (G) T-La (FS) and (H) RGD-T-La (FS). T-La, Temporin-La; (FS), antitumor.
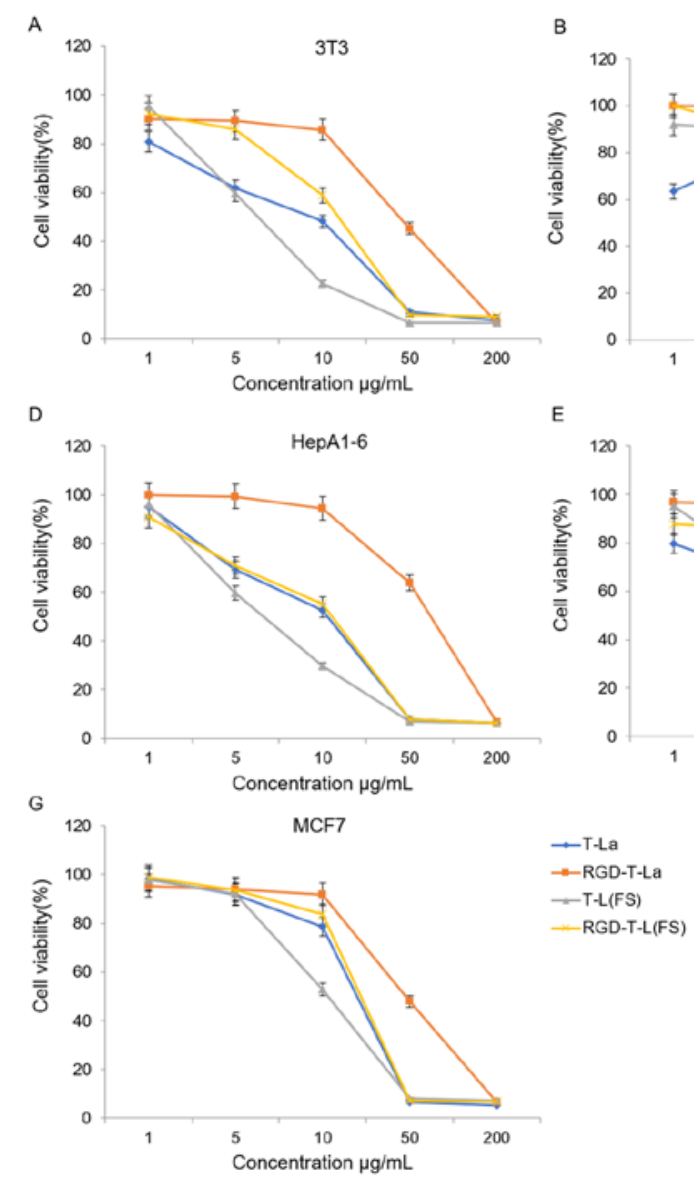
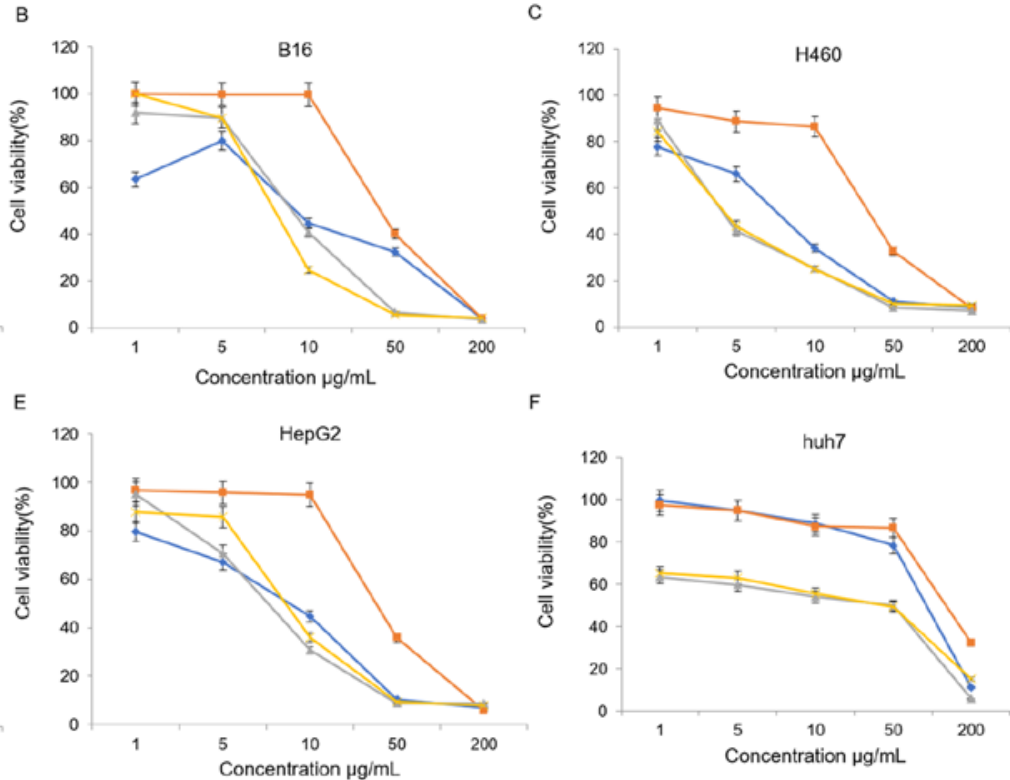

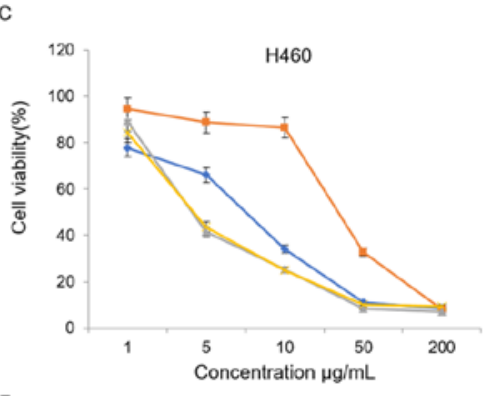

Figure 3. Antitumor activity measured using an MTT assay in (A) 3T3, (B) B16, (C) H460, (D) HepA1-6, (E) HepG2, (F) huh7 and (G) MCF7cell lines after treatment with anti-tumor peptides and their RGD chimeras. T-La, Temporin-La; (FS), antitumor.

Western blot analysis of caspase-3 protein expression. B16 melanoma cells were treated with $0,10,20,50$ and $100 \mu \mathrm{g} / \mathrm{ml}$ of peptide for $24 \mathrm{~h}$. A representative western blot for apoptotic protein caspase-3 is shown in Fig. 6 and quanti- fication is shown in Fig. 7. Expression of caspase-3 was more abundant after RGD-T-La (FS) treatment in B16 cells at 10 and $20 \mu \mathrm{g} / \mathrm{ml}$ compared with the control group and the expression of caspase-3 was significantly higher compared with 

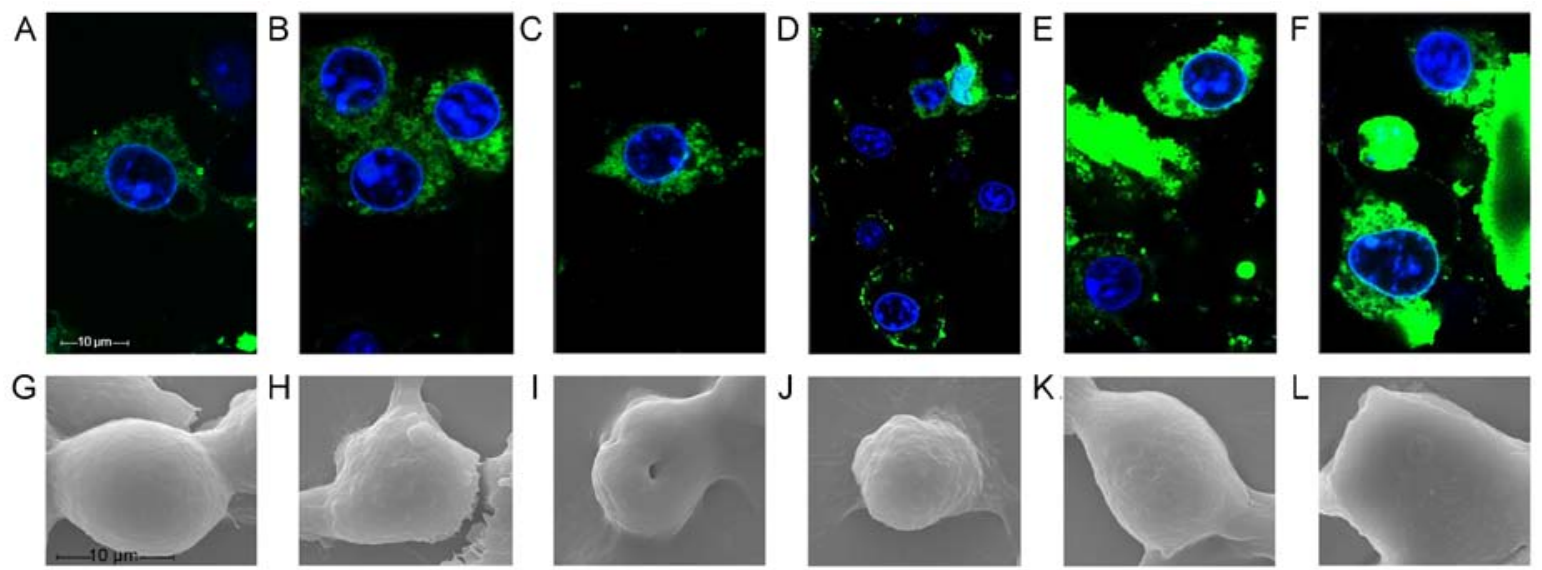

Figure 4. Real-time observation and scanning electron microscopy of the effects of novel antitumor peptides on B16 cells. Morphology of B16 cells treated with fluorescein isothiocyanate-RGD-T-La (FS) for (A) 20, (B) 40, (C) 50, (D) 70, (E) 100 and (F) 110 min. B16 cells treated with (G) 10 , (H) 50 and (I) $200 \mu \mathrm{g} / \mathrm{ml}$ RGD-T-La (FS) peptide. B16 cells treated with (J) 10, (K) 50 and (L) $200 \mu \mathrm{g} / \mathrm{ml}$ T-La (FS) peptide. T-La, Temporin-La; (FS), antitumor.
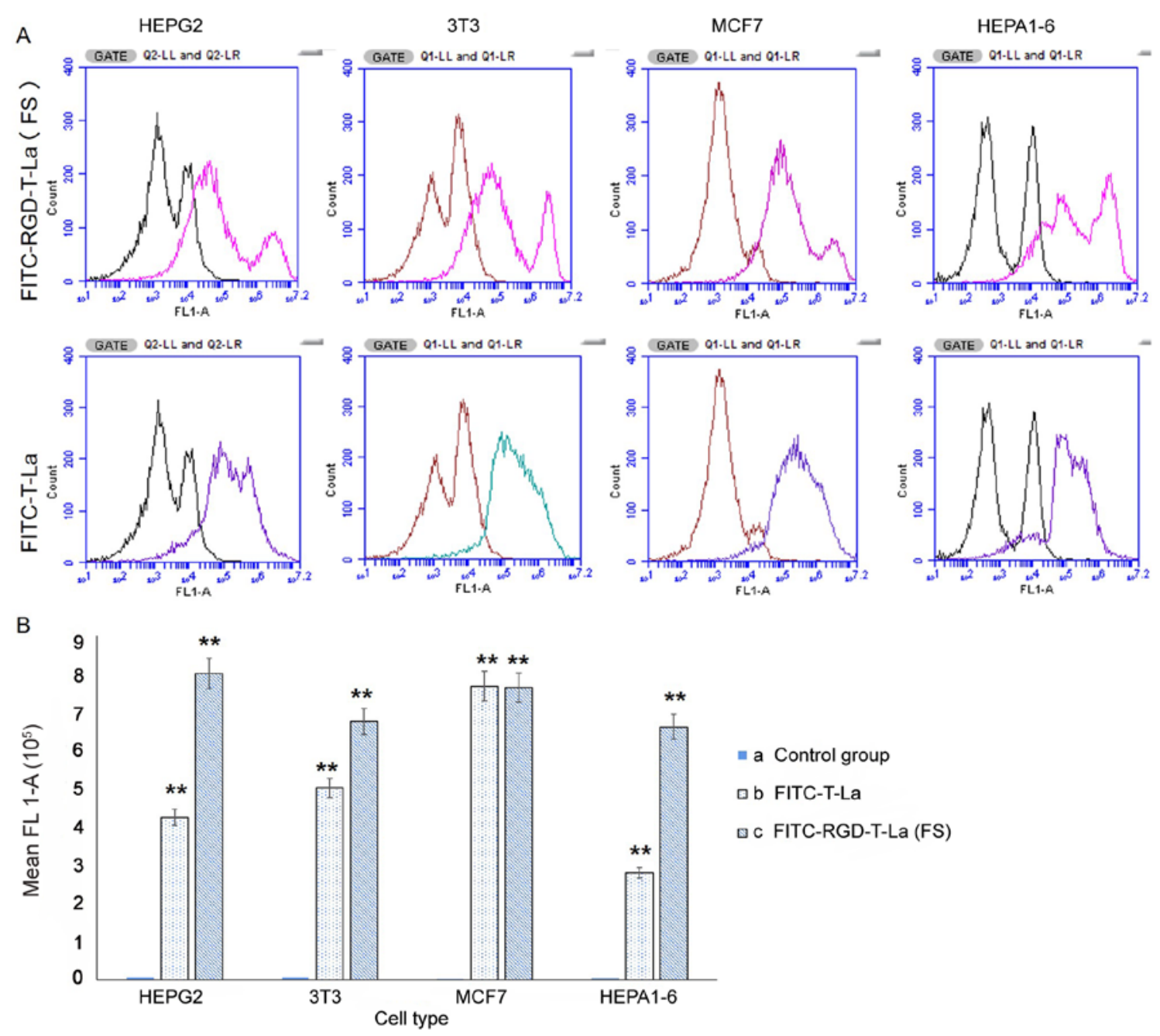

Figure 5. Flow cytometry analysis and quantification of integrin $\alpha v \beta 3$ expression. (A) Curve of fluorescence for FITC-RGD-T-La (FS) and FITC-RGD-T-La. (B) Quantification of integrin $\alpha v \beta 3$ flow cytometry signal intensity. $\mathrm{n}=3$ /group. $\mathrm{P}<0.05$ and ${ }^{* *} \mathrm{P}<0.001$ vs. control group. T-La, Temporin-La; (FS), antitumor; FITC, fluorescein isothiocyanate.

other peptides groups at $50 \mu \mathrm{g} / \mathrm{ml}$. With increasing peptide concentration, the expression of caspase- 3 protein gradually decreased, which may have led to cell death.
RT-qPCR analysis of apoptotic gene caspase- 3 mRNA expression. The effects of peptide treatment on the expression of caspase-3 mRNA in B16 cells were determined using qPCR. 
Table II. Effect of T-La (S) and RGD-T-La (S) on mRNA expression of apoptosis gene in B16 cells.

\begin{tabular}{lc}
\hline Peptide & Caspase-3 expression (mean \pm SEM) \\
\hline Control & $0.62 \pm 0.04$ \\
T-La $(\mathrm{S}), \mu \mathrm{g} / \mathrm{ml}$ & $0.83 \pm 0.13$ \\
10 & $0.78 \pm 0.20$ \\
20 & $0.61 \pm 0.09$ \\
50 & \\
RGD-T-La (S), $\mu \mathrm{g} / \mathrm{ml}$ & $1.32 \pm 0.04^{\mathrm{b}}$ \\
10 & $1.06 \pm 0.22^{\mathrm{a}}$ \\
20 & $0.42 \pm 0.1$ \\
50 & \\
T-La (FS), $\mu \mathrm{g} / \mathrm{ml}$ & $1.37 \pm 0.09^{\mathrm{b}}$ \\
10 & $0.39 \pm 0.08$ \\
20 & $0.25 \pm 0.16$ \\
50 & \\
RGD-T-La (FS), $\mu \mathrm{g} / \mathrm{ml}$ & $1.27 \pm 0.12^{\mathrm{a}}$ \\
10 & $0.81 \pm 0.16$ \\
20 & $0.35 \pm 0.12$ \\
50 &
\end{tabular}

${ }^{\mathrm{a}} \mathrm{P}<0.05$ and ${ }^{\mathrm{b}} \mathrm{P}<0.001$ vs. control. T-La, Temporin-La; (FS), antitumor; (S), antitumor.

Compared with the control group, $10 \mu \mathrm{g} / \mathrm{ml}$ of RGD-T-La (S), RGD-T-La (FS) and T-La (FS) induced significantly higher expression of caspase-3 apoptotic gene mRNA in B16 cells $(\mathrm{P}<0.05)$ (Table II). These results were consistent with the western blotting results. However, treatment with T-La (S) did not significantly alter caspase-3 mRNA levels compared with controls (Table II).

Distribution of antitumor peptide RGD-T-La (FS) in different organs and tumor tissues. After 30 min post tail vein injection, the antitumor peptide, RGD-T-La (FS), was distributed in the tumors, liver, lung and kidney of nude mice. After $1 \mathrm{~h}$ post injection, fluorescence was observed in the heart, liver, lung, kidney and tumors, but the fluorescence intensity was strongest in the tumors. After $4 \mathrm{~h}$ post injection, the fluorescence in tumors was higher compared with in the fluorescence in heart, liver, spleen, lung and kidney. After $8 \mathrm{~h}$, the fluorescence in heart, liver, spleen, lung and kidney disappeared, but fluorescence was still observed in the tumor tissues. In the T-La (FS) group and PBS group, no fluorescence was observed (Fig. 8).

Histopathological observation of tumor tissue. After RGD-T-La (FS) injection, tumor cell necrosis was observed. The cellular structure was broken down and fragmentation of the nucleus was observed. In the control group, tumor cells with blurred margins, degeneration, necrosis and mitotic phase were observed (Fig. 9). In addition, the four peptides had no side effects on normal nude mice tissues, and the results of tissue sections are shown in Figs. S1-S4.

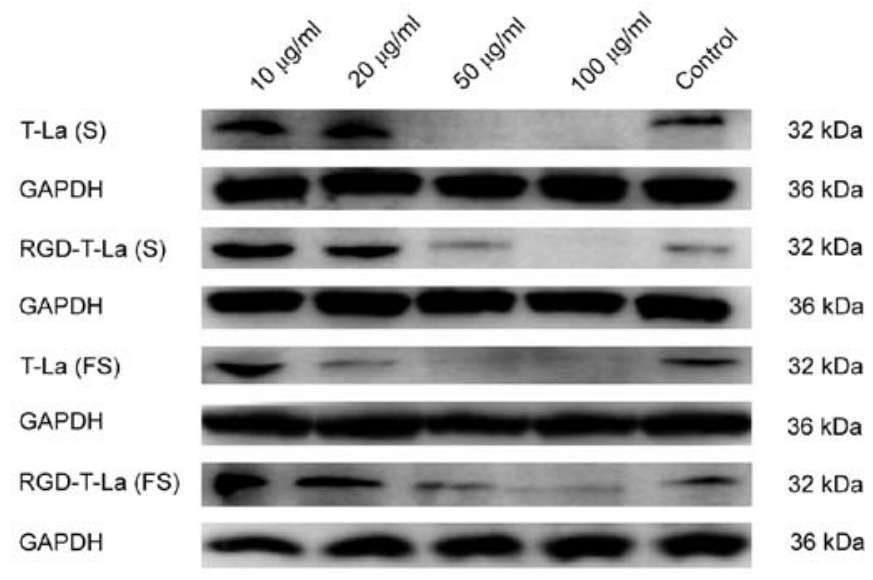

Figure 6. Representative western blotting showing caspase-3 protein expression in six melanoma cells treated with $0,10,20,50$ and $100 \mu \mathrm{g} / \mathrm{ml}$ of the indicated peptide for $24 \mathrm{~h}$. T-La, Temporin-La; (FS), antitumor; (S), antitumor.

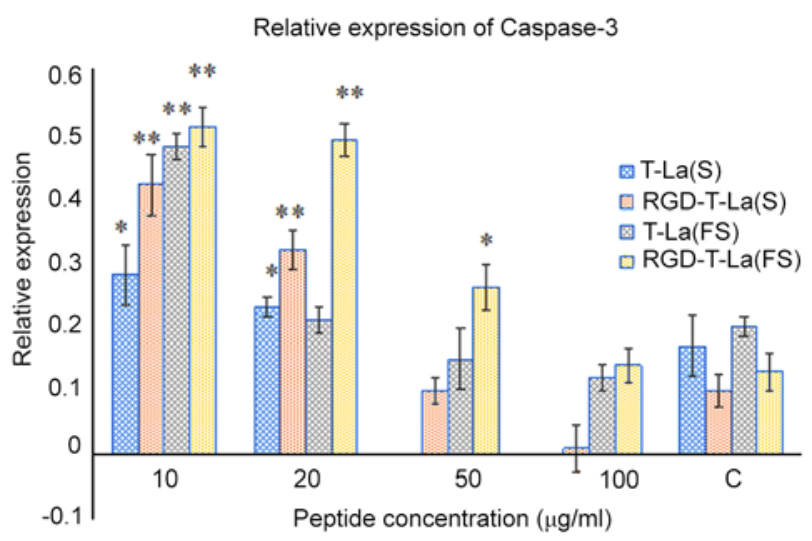

Figure 7. Quantification of western blots showing caspase-3 protein expression in six melanoma cells treated with $0,10,20,50$ and $100 \mu \mathrm{g} / \mathrm{m}$ of the indicated peptide for $24 \mathrm{~h}$. Values are given as mean $\pm \mathrm{SD}$ of three independent experiments in duplicates. ${ }^{*} \mathrm{P}<0.05$ and ${ }^{* *} \mathrm{P}<0.01$ vs. control. T-La, Temporin-La; (FS), antitumor; (S), antitumor.

Effects of antitumor peptides on mouse body weight and melanoma growth. Body weights did not differ significantly between the groups before treatment (Table III). Treatment with the peptides resulted in positive weight gain in tumor-bearing mice (Table III). After the first four injections, the average weight gain in each peptide treatment group was significantly higher compared with that in the cisplatin and PBS groups (all $\mathrm{P}<0.05)$. One week after the fifth drug administration, weight gain between the treatment groups was not significantly different $(\mathrm{P}>0.05)$.

As shown in Table IV, the initial tumor volumes in each experimental group were not significantly different $(\mathrm{P}=0.306)$. After the first treatment, the tumor volume increased significantly in the PBS control group compared with the other treatment groups (all $\mathrm{P}<0.05$ ). There were no significant differences in tumor volume changes between the antitumor peptide groups and the cisplatin treatment group (all $\mathrm{P}>0.05$ ). After the second treatment, the tumor volume increase in the RGD-T-La group was significantly smaller compared with the PBS group $\mathrm{P}=0.018$ ) (Table IV). The tumor volume increases 

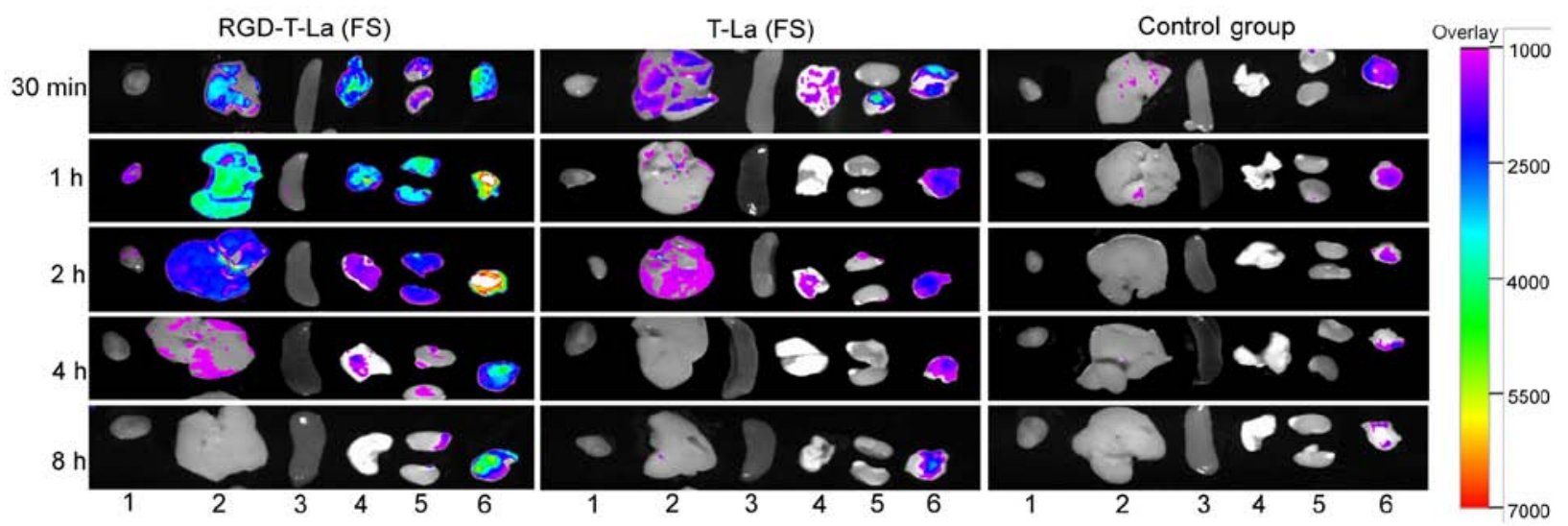

Figure 8. Distribution of antineoplastic peptides in different organs and tumor tissues of nude mice at different times. Heart, liver, spleen, lung, kidney and tumor tissues are denoted by 1,2,3,4,5 and 6, respectively. Change of color in the tissue represents the intensity of fluorescence, and purple to red indicates that the fluorescence intensity changes from weak to strong. T-La, Temporin-La; (FS), antitumor.

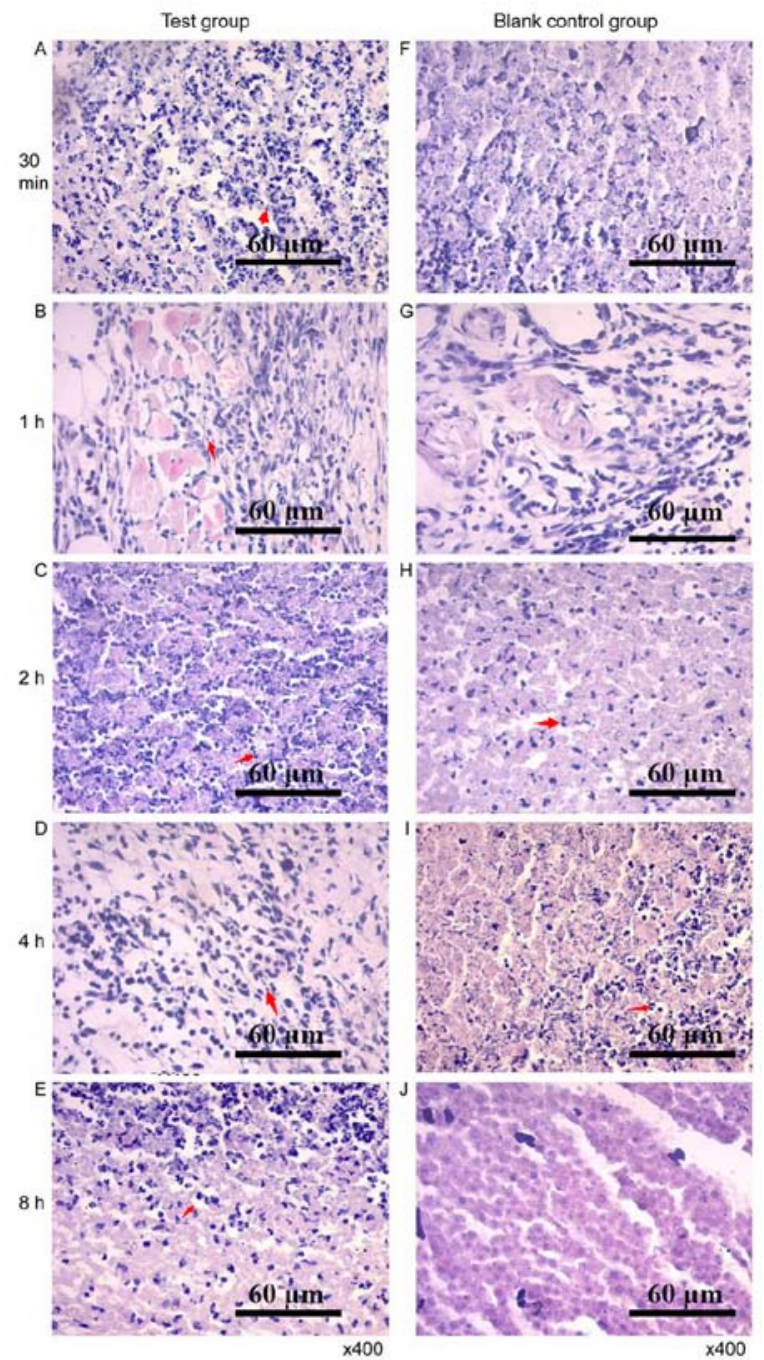

Figure 9. Pathological map of tumor tissues. Sections of tumor tissues in the experimental group at (A) $30 \mathrm{~min}$, (B) 1, (C) 2, (D) 4 and (E) $8 \mathrm{~h}$ after treatment, respectively. Sections of tumor tissues in the control group at (F) $30 \mathrm{~min}$, (G) 1, (H) 2, (I) 4 and (J) $8 \mathrm{~h}$ after treatment.

in the other treatment groups were not significantly different (all P>0.05; Table IV).
Evaluation of VEGF and caspase-3 expression using immunohistochemistry. Evaluation of tumor sections using immunohistochemistry showed that, in melanoma cells, VEGF was expressed mostly on the tumor cell membrane surface. VEGF expression was higher in superficial tumor cells compared with in cells toward the center of the tumor. Caspase-3 was primarily expressed in the nucleus and around necrotic foci in tumor nodules. The expression of VEGF was lower in all peptide treatment groups [T-La (FS), RGD-T-La (FS), T-La and RGD-T-La] compared with the PBS control group (Fig. 10). Expression of caspase-3 was higher in the antitumor peptide treatment groups [T-La (FS), RGD-T-La (FS), T-La and RGD-T-La] compared with in the PBS treatment control group (Fig. 10).

\section{Discussion}

Analysis of the structure and activity of a large number of antimicrobial peptides has revealed that the peptide structure is related to its activity (15). A recent study has shown that the positive charge number, hydrophobicity, $\alpha$-helix, amphoteric molecular structure, disulfide bonds and other factors of antimicrobial peptides have important effects on their activity (16). The present study focused on four peptides, including T-La, T-La (FS) and the chimeric peptides, RGD-T-La and RGD-T-La (FS). Glutamate (E) is a negatively charged amino acid and serine is an uncharged polar amino acid (5). Both leucine and phenylalanine are uncharged non-polar hydrophobic amino acids (5). Increased hydrophobicity has been shown to increase antimicrobial activity of peptides (17). Likewise, an increase in amphiphilicity can increase the activity of antimicrobial peptides (18). In the present study, the antitumor activity of T-La (FS) was higher compared with that of T-La, and the antitumor activity of chimeric RGD-T-La (FS) was higher compared with that of chimeric RGD-T-La. The effects of four polypeptides at different concentrations on different cells were compared, and it was demonstrated that the increase in charge was the main reason for differences in antitumor activities of the polypeptides. The increase in net charge increased the concentration of polypeptide on the cell membrane surface, and differences in hydrophobicity and amphiphilicity 
Table III. Comparison of body weight before and $48 \mathrm{~h}$ after injection of nude mice with antitumor drugs.

\begin{tabular}{|c|c|c|c|c|c|c|}
\hline \multirow[b]{2}{*}{ Drug } & \multirow[b]{2}{*}{ Initial weight, $\mathrm{g}$} & \multicolumn{5}{|c|}{ Weight increase after administration, $\mathrm{g}$} \\
\hline & & First & Second & Third & Fourth & Fifth \\
\hline T-La (FS) & $\begin{array}{c}20.540 \pm \\
0.3855^{\mathrm{a}}\end{array}$ & $\begin{array}{l}0.850 \pm \\
0.1839^{\mathrm{a}}\end{array}$ & $\begin{array}{l}0.850 \pm \\
0.1821^{\mathrm{a}}\end{array}$ & $\begin{array}{l}0.817 \pm \\
0.3229^{\mathrm{a}}\end{array}$ & $\begin{array}{l}1.017 \pm \\
0.3038^{\mathrm{a}}\end{array}$ & $\begin{array}{l}2.533 \pm \\
0.6800^{\mathrm{a}}\end{array}$ \\
\hline RGD-T-La (FS) & $\begin{array}{r}20.360 \pm \\
0.2874^{\mathrm{a}}\end{array}$ & $\begin{array}{l}0.667 \pm \\
0.1382^{\mathrm{a}, \mathrm{b}}\end{array}$ & $\begin{array}{l}0.783 \pm \\
0.1138^{\mathrm{a}}\end{array}$ & $\begin{array}{l}1.017 \pm \\
0.3229^{a}\end{array}$ & $\begin{array}{l}1.467 \pm \\
0.3792^{\mathrm{a}}\end{array}$ & $\begin{array}{c}0.483 \pm \\
1.4363^{\mathrm{a}}\end{array}$ \\
\hline $\mathrm{T}-\mathrm{La}$ & $\begin{array}{c}19.620 \pm \\
0.4128^{\mathrm{a}}\end{array}$ & $\begin{array}{l}0.300 \pm \\
0.2295^{\mathrm{a}, \mathrm{b}}\end{array}$ & $\begin{array}{l}0.917 \pm \\
0.3449^{\mathrm{a}}\end{array}$ & $\begin{array}{l}1.333 \pm \\
0.3229^{\mathrm{a}}\end{array}$ & $\begin{array}{l}0.200 \pm \\
0.4933^{a}\end{array}$ & $\begin{array}{l}1.917 \pm \\
0.4936^{\mathrm{a}}\end{array}$ \\
\hline RGD-T-La & $\begin{array}{c}19.940 \pm \\
0.5680^{\mathrm{a}}\end{array}$ & $\begin{array}{l}0.400 \pm \\
0.1000^{\mathrm{a}, \mathrm{b}}\end{array}$ & $\begin{array}{l}0.383 \pm \\
0.2496^{\mathrm{a}}\end{array}$ & $\begin{array}{l}0.983 \pm \\
0.3229^{a}\end{array}$ & $\begin{array}{l}1.400 \pm \\
0.3286^{\mathrm{a}}\end{array}$ & $\begin{array}{l}0.883 \pm \\
0.3919^{\mathrm{a}}\end{array}$ \\
\hline Cisplatin positive control & $\begin{array}{r}19.680 \pm \\
0.5152^{\mathrm{a}}\end{array}$ & $\begin{array}{c}-0.050 \pm \\
0.3149^{\mathrm{b}}\end{array}$ & $\begin{array}{c}-0.950 \pm \\
0.3871^{\mathrm{b}}\end{array}$ & $\begin{array}{c}-1.983 \pm \\
0.3229^{\mathrm{b}}\end{array}$ & $\begin{array}{c}-3.683 \pm \\
0.5043^{b}\end{array}$ & NA \\
\hline PBS blank control & $\begin{array}{c}20.400 \pm \\
0.4050^{\mathrm{a}}\end{array}$ & $\begin{array}{c}-1.067 \pm \\
0.4917^{c}\end{array}$ & $\begin{array}{c}-0.667 \pm \\
0.4780^{\mathrm{b}}\end{array}$ & $\begin{array}{l}0.017 \pm \\
0.3229^{b}\end{array}$ & $\begin{array}{c}-2.017 \pm \\
0.4708^{c}\end{array}$ & $\begin{array}{l}1.267 \pm \\
0.8123^{a}\end{array}$ \\
\hline
\end{tabular}

${ }^{\mathrm{a}} \mathrm{P}<0.05$ and ${ }^{\mathrm{b}} \mathrm{P}<0.001$ vs. PBS blank control. T-La, Temporin-La; (FS), antitumor; (S), antitumor.

Table IV. Melanoma tumor volume in nude mice before and $48 \mathrm{~h}$ after injection of anti-tumor drugs

Tumor volume,

\begin{tabular}{|c|c|c|c|c|c|c|}
\hline \multirow[b]{2}{*}{ Item } & \multirow[b]{2}{*}{ Primary tumor volume, $\mathrm{mm}^{3}$} & \\
\hline & & First & Second & Third & Fourth & Fifth \\
\hline \multirow[t]{2}{*}{ T-La (FS) } & $21.1022 \pm$ & $25.3020 \pm$ & $19.8162 \pm$ & $20.6351 \pm$ & $27.0552 \pm$ & $134.1800 \pm$ \\
\hline & $2.48719^{\mathrm{a}}$ & $3.04705^{\mathrm{b}}$ & $2.69010^{\mathrm{a}, \mathrm{b}}$ & $3.42328^{\mathrm{a}}$ & $5.39173^{\mathrm{a}}$ & $14.22572^{\mathrm{a}}$ \\
\hline \multirow[t]{2}{*}{ RGD-T-L (FS) } & $38.9477 \pm$ & $38.5640 \pm$ & $25.6673 \pm$ & $12.9156 \pm$ & $32.1026 \pm$ & $82.8592 \pm$ \\
\hline & $11.16416^{\mathrm{a}}$ & $6.22073^{\mathrm{b}}$ & $1.93695^{\mathrm{a}}$ & $15.98864^{\mathrm{a}}$ & $11.98846^{\mathrm{a}}$ & $25.75526^{\mathrm{a}}$ \\
\hline \multirow[t]{2}{*}{ T-La } & $26.6849 \pm$ & $33.3320 \pm$ & $19.5228 \pm$ & $20.0724 \pm$ & $32.6486 \pm$ & $100.7889 \pm$ \\
\hline & $5.36854^{\mathrm{a}}$ & $8.72730^{\mathrm{b}}$ & $3.78134^{\mathrm{a}, \mathrm{b}}$ & $3.76676^{\mathrm{a}}$ & $5.07784^{\mathrm{a}}$ & $10.08681^{\mathrm{a}}$ \\
\hline \multirow[t]{2}{*}{ RGD-T-La } & $24.3425 \pm$ & $27.9720 \pm$ & $10.7225 \pm$ & $18.8990 \pm$ & $32.6512 \pm$ & $83.0283 \pm$ \\
\hline & $3.35537^{\mathrm{a}}$ & $5.69018^{\mathrm{b}}$ & $2.03661^{\mathrm{b}}$ & $2.16945^{\mathrm{a}}$ & $5.11254^{\mathrm{a}}$ & $18.52589^{\mathrm{a}}$ \\
\hline \multirow[t]{2}{*}{ Cisplatin positive control } & $23.9659 \pm$ & $34.4100 \pm$ & $14.2439 \pm$ & $13.1352 \pm$ & $3.5965 \pm$ & / \\
\hline & $5.18682^{\mathrm{a}}$ & $7.04033^{\mathrm{b}}$ & $4.04242^{\mathrm{a}, \mathrm{b}}$ & $5.14370^{\mathrm{a}}$ & $4.20833^{b}$ & \\
\hline \multirow[t]{2}{*}{ PBS blank control } & $32.2281 \pm$ & $62.0960 \pm$ & $25.9056 \pm$ & $25.8578 \pm$ & $22.9230 \pm$ & $114.2617 \pm$ \\
\hline & $2.09646^{\mathrm{a}}$ & $5.50607^{\mathrm{a}}$ & $7.16902^{\mathrm{a}}$ & $4.13521^{\mathrm{a}}$ & $3.37649^{\mathrm{a}}$ & $13.95786^{\mathrm{a}}$ \\
\hline
\end{tabular}

Data are presented as mean $\pm \mathrm{SE}, \mathrm{n}=6$. ${ }^{\mathrm{a}} \mathrm{P}<0.05,{ }^{\mathrm{b}} \mathrm{P}<0.001$ and ${ }^{\mathrm{a}, \mathrm{b}} \mathrm{P}>0.05$ vs. PBS blank control.

also contributed to differences in antitumor activity. The present study provides a scientific basis for the application of small molecule antimicrobial peptides as antitumor agents. Furthermore, the current study established the theoretical foundation for the development and clinical application of these peptides as antitumor drugs. By combining the targeting effect of the RGD peptide with the antitumor effect of the T-La peptide, the antitumor effects were improved.

Observation of polypeptide effects in real time using laser confocal microscopy revealed that the peptides elicited a very rapid effect on cells. The mechanism of action of the polypeptides and RGD chimeras was observed using scanning electron microscopy, and it was reported that the RGD-conjugated chimeric peptide caused loss of cytoplasm and cell death by rapidly acting on a specific target on the cell membrane. The non-chimeric polypeptide acted on the entire cell membrane surface, causing cell membrane lysis and cell death.

Integrin proteins on the surface of most tumor cell membranes are transmembrane receptors that mediate cross-talk between tumor cells and their external environment (19). In the process of contacting tumor cells and the external environment, integrins not only play a transmembrane role, but also participate in the transmission of signals between cells and their external environment (20). Integrin 

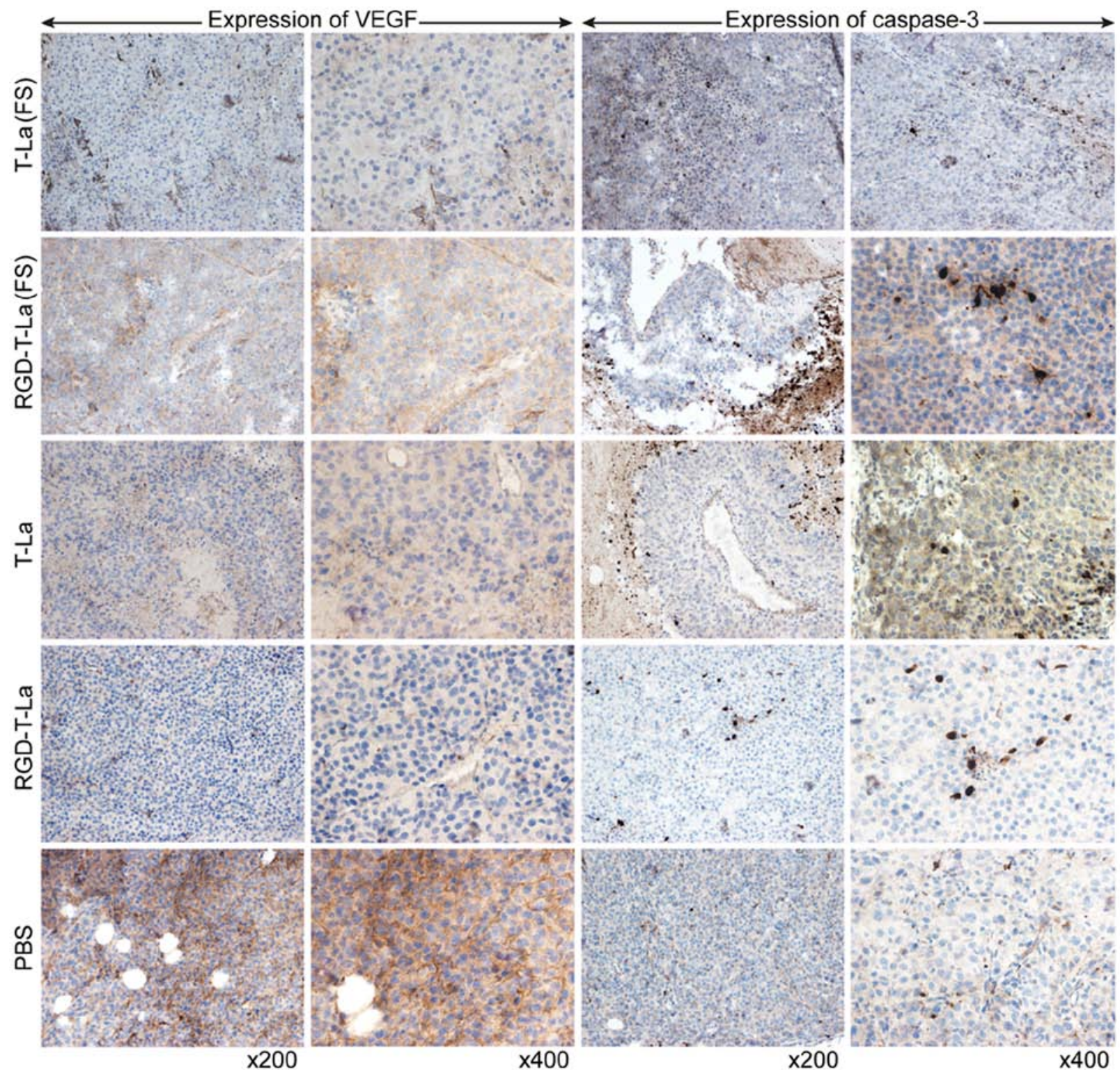

Figure 10. Expression of VEGF and caspase-3 in melanoma tumors from nude mice treated with antitumor peptides. T-La, Temporin-La; (FS), antitumor.

$\alpha v \beta 3$ serves an important role in tumor angiogenesis and is highly expressed on a variety of tumor surfaces and neovascular endothelial cells (21). Targeting $\alpha v \beta 3$ for the detection and diagnosis of a variety of tumors, such as melanoma has been widely evaluated and used (22). The RGD small molecule peptide used in the present study is a ligand for integrin $\alpha v \beta 3$ and was conjugated to the engineered antitumor peptides to enhance the targeting of the peptides to tumor cells. The current data may aid the development of targeted antitumor drugs in this regard.

The weights of tumor-bearing nude mice in the antitumor peptide treatment groups demonstrated an increasing trend after the first three doses, while the weights of mice treated with the cisplatin positive control and PBS negative control decreased. These data suggested that the antitumor peptides had less severe side effects on animal health. In addition, the four peptides have no side effects on normal nude mice tissues. The cisplatin treatment significantly inhibited melanoma tumor growth in nude mice, but the dose of $100 \mu \mathrm{l} / 1 \mathrm{mg} / \mathrm{ml}$ caused harm to the animals, as indicated by the weight loss. These data indicated that the antitumor peptides exerted their inhibitory effect on melanoma tumor growth in nude mice during the early stages of cancer treatment.

Under non-pathological conditions, VEGF is expressed mainly in the cytoplasm and on the membranes of vascular endothelial cells $(23,24)$. The expression of VEGF in tumor cells treated with antitumor peptides was lower compared with that in the PBS group, indicating that the peptides could effectively inhibit VEGF expression $(25,26)$. The apoptotic protein caspase- 3 promotes apoptosis of tumor cells (27), and higher caspase-3 expression indicates higher degrees of tumor cell apoptosis (28). The present study reported that caspase-3 expression in melanoma tissues of nude mice treated with the antitumor peptides was higher compared with that in the PBS control group. These data suggested that the antitumor peptides induce apoptosis through a combined effect on VEGF and caspase-3; however, more experiments are needed to fully elucidate the inhibitory effects of the peptides on 
tumor growth. For example, repetitive testing of target animals in vivo. Compared with previously reported articles $(5,27,28)$, the T-La peptide sequence was modified resulting in stronger antitumor effects in vitro and in vivo. Coupling the modified peptides with the RGD peptide increased their targeting ability. Therefore, the current study highlight the potential of RGD-T-La (S) and RGD-T-La (FS) as safe drugs in the treatment of melanoma.

Overall, with the aim to improve the antineoplastic activity of the antimicrobial peptide T-La from bullfrog skin, the present study constructed a novel chimeric peptide by altering several amino acids in the peptide and coupling the peptide to the small molecular peptide, RGD. The resulting peptide, RGD-T-La (FS), had altered physical and chemical properties, including changes in the charge number, isoelectric point and hydrophobicity. Furthermore, in vitro and in vivo experiments showed that RGD-T-La (FS) had strong growth inhibitory effects in tumor cells, acted on tumor tissues in nude mice for a longer time and had significant inhibitory effects on melanoma.

\section{Acknowledgements}

Not applicable.

\section{Funding}

The present study was funded by grants from The General Fund of Application Foundation \& Advanced Technology Program, Tianjing, China (grant nos. 14JCYBJC3000 and 18JCYBJC30100), The Veterinary 'Innovative Talent People of Young and Middle Age Key Members Project' of Tianjin, China, The National Natural Science Foundation of China (grant no. 31201886, 31572492) and The '131' Innovative Talents Training Project Third Level Candidate Program, Tianjin.

\section{Availability of data and materials}

The datasets used and/or analyzed during the current study are available from the corresponding author on reasonable request.

\section{Authors' contributions}

ML and RZ participated in the study design, analyzed the data and drafted the manuscript. ML and XJ carried out most of the experiments and collected the data. CF and TJ were involved with study design and analyzing data. TJ was involved in drafting the manuscript. JM, SQ, LAL, YH and XZ analyzed data. All authors read and approved the final manuscript.

\section{Ethics approval and consent to participate}

All animal experiments were approved by The Laboratory Animal Ethics Committee of Tianjin Medical University (approval no. TMUaMEC 2018036) (Tianjin, China).

\section{Patient consent for publication}

Not applicable.

\section{Competing interests}

The authors declare that they have no competing interests.

\section{References}

1. Li S, Hao L, Bao W, Zhang P, Su D, Cheng Y, Nie L, Wang G, Hou F and Yang Y: A novel short anionic antibacterial peptide isolated from the skin of Xenopus laevis with broad antibacterial activity and inhibitory activity against breast cancer cell. Arch Microbiol 198: 473-482, 2016.

2. Zhang F and Li MS: Antibacterial peptides' roles in immune defense and anti-tumorogenesis. World Not Antibiot 38: 284-289, 2017 (In Chinese)

3. Gao J, Xie C and Lu WY: Progress in research of antitumor activity of antimicrobial peptides. World Clinical Drugs, 10: 12, 2012.

4. Zhu LZR, Liu SS, Ma JF, Jin TM, Liu JF, Hu Y and Liu MY: Biological activity and in vivo tissue targeting distribution of catesbeianalctin. Chin J Vet Sci 36: 185-190, 2016 (In Chinese).

5. Diao Y, Han W, Zhao H, Zhu S, Liu X, Feng X, Gu J, Yao C, Liu S, Sun C, et al: Designed synthetic analogs of the $\alpha$-helical peptide temporin-La with improved antitumor efficacies via charge modification and incorporation of the integrin $\alpha v \beta 3$ homing domain. J Pept Sci 18: 476-486, 2012.

6. Ma L, Cai ZL, Wang QR and Lei CX: Study on construction of citrostatin and its bioactivity. Chin J Biochem Pharm 31: 19-22, 2010.

7. Huang R, Long J and Zhang Y: Synthesise and activity of dual targeted antineoplastic polypeptide RGDSY-CTTHWGFTLC. Cancer Res Prev Treat 41: 531-535, 2014.

8. Ma Q, Dong N, Cao Y and Shan A: Rational design of alpha-helical antimicrobial peptide with Val and Arg residues. Acta Microbiol Sin 51: 346-451, 2011.

9. Wang XX, Niu B, Chen XJ, Xie J and Zhang YH: Synthesis and activities of RGD peptide analog. J Chin Pharm Sci. 43: 462-464, 2008 (In Chinese).

10. Liu KY, Li QW and Liu GY: Study progress of malignant tumor imaging of integrin $\alpha v \beta 3$ expression with radiolabelled RGD peptides. Medical Recapitulate 12: 757-759, 2006 (In Chinese).

11. Zhang CL, Yang $M$ and Wang RF: The structure-activity relationship of RGD peptides binding to $\alpha v \beta 3$ integrin and radiolabeled ligand design. J Oncol 15: 76-81, 2009.

12. Yu YP, Wang Q, Liu YC and Xie Y: Molecular basis for the targeted binding of RGD-containing peptide to integrin $\alpha v \beta 3$. Biomaterials 35: 1667-1675, 2014.

13. Ji QZ and Zhang KW: Observation of DFRKN-1 isolate by scanning electron microscope. Anhui Agric Sci 39: 33-34, 2011.

14. Seo GY, Ha Y, Park AH, Kwon OW and Kim YJ: Leathesia difformis extract inhibits $\alpha$-MSH-induced melanogenesis in B16F10 cells via down-regulation of CREB signaling pathway. Int J Mol Sci 20: E536, 2019.

15. Zhang CL, Wang RF and L Z: Design of $\sim(131)$ I labeling of a disulfide bridged RGD-peptide targeted to integrin $\alpha v \beta 3$ receptor and its biodistribution and imaging in tumor bearing mice. J Oncol 16: 276-280, 2010.

16. Dia YW: Design for tumor-targeting antimicrobial peptide chimera and its anticancer mechanism study (unpublished $\mathrm{PhD}$ thesis). Jilin University, 2012.

17. Li ZDLY and Zhen YS: Potentiation of boanmycin antitumor activity by chemotactic peptide. Chin J Cancer Res 17: 79-83, 2005 (In Chinese).

18. Zhao RL, Han JY, Han WY, Liu SS, Ma JF, Lei LC, Feng X, Zhang AG and Wang $X$ : The antibacterial and antitumor function of a novel bio-active peptide Catesbeianin-1a of Rana catesbeiana. Chin J Vet Sci 33: 1407-1411, 2013 (In Chinese).

19. Wang LZ and Min Y: Advance of" 1 " 8 F labeled RGD peptide as integrin $\alpha \_V \beta \_3$ receptor imaging agents. J Isot 24: 68-75, 2011.

20. Jiang Z, Vasil AI, Hale JD, Hancock RE, Vasil ML and Hodges RS: Effects of net charge and the number of positively charged residues on the biological activity of amphipathic $\alpha$-helical cationic antimicrobial peptides. Biopolymers 90: 369-383, 2008.

21. Zhang J, Xiao X, Zhu J, Gao Z, Lai X, Zhu X and Mao G: Lactoferrin- and RGD-comodified, temozolomide and vincristine-coloaded nanostructured lipid carriers for gliomatosis cerebri combination therapy. Int $\mathbf{J}$ Nanomedicine 13: 3039-3051, 2018. 
22. Chen T, Chen L, He H, Peng J, Guo X and Zheng Y and Shao C: Influence of HAnps carrier system with doping $\mathrm{Mg}$ and grafting RGD on endocytosis of MG63 cells. J Cent South Univ 48: 625-634, 2017.

23. Habibi N, Kamaly N, Memic A and Shafiee H: Self-assembled peptide-based nanostructures: Smart nanomaterials toward targeted drug delivery. Nano Today 11: 41-60, 2016.

24. Lambert E, Fuselier E, Ramont L, Brassart B, Dukic S, Oudart JB, Dupont-Deshorgue A, Sellier C, Machado C and Dauchez M: Conformation-dependent binding of a Tetrastatin peptide to $\alpha v \beta 3$ integrin decreases melanoma progression through $\mathrm{FAK} / \mathrm{PI}_{3} \mathrm{~K} / \mathrm{Akt}$ pathway inhibition. Sci Rep 8: 9837, 2018.

25. Hou J, Diao Y, Li W, Yang Z, Zhang L, Chen Z and Wu Y: RGD peptide conjugation results in enhanced antitumor activity of PD0325901 against glioblastoma by both tumor-targeting delivery and combination therapy. Int J Pharm 505: 329-340, 2016.
26. Chen G, Yu F, Sheng G, Wang J and Qu B: Progress and future direction of vascular mimicry. J Mod Oncol 1: 138-141, 2017.

27. Cao QZ and Lin ZB: Antitumor and anti-angiogenic activity of Ganoderma lucidum polysaccharides peptide. Acta Pharmacol Sin 25: 833-838, 2004.

28. Ren HD, Zhang L, Zhao Y, Si XH, Zhang L and Wang C: Study on inhibitory effect of antimicrobial peptide Temporin-1CEa and its analogues inhibit metastasis and invasion of human melanoma A375 cells and reduce angiogenesis. Chin J Biochem Pharm 2: 19-22, 2016 (In Chinese).

(i) (2) This work is licensed under a Creative Commons Attribution-NonCommercial-NoDerivatives 4.0 International (CC BY-NC-ND 4.0) License. 